\title{
UNA APROXIMACIÓN LITERARIA A LA RELACIÓN ENTRE LA JUSTICIA Y EL DERECHO
}

\author{
Pedro Talavera ${ }^{1}$
}

\begin{abstract}
RESUMEN: Considerando la Literatura como un "género de investigación", de acuerdo con la propuesta de Rorty, el presente trabajo pretende mostrar el enorme potencial prefigurador $\mathrm{y}$ transformador que determinadas obras literarias han ejercido en la evolución del pensamiento y de los modelos organizativos de la vida social, anticipando un cambio de paradigma en la relación entre la Justicia y el Derecho en tres escenarios históricos cruciales: el clásico, que propone vincular la justicia al respeto de la ley (La Orestiada); el moderno, que fundamenta la justicia sobre principios éticos universales y la garantía de derechos (El mercader de Venecia); y el pensamiento nihilista postmoderno, de matriz nietzscheana, que tiende a disolver ambos conceptos (Crimen y Castigo).
\end{abstract}

Pálabras Clave: derecho y literatura; justicia; venganza; moral; postmodernidad.

\section{INTRODUCCIÓN}

Resulta ya casi un tópico referirse a la relación entre el Derecho y la Literatura. Son abundantísimos los trabajos académicos dedicados al análisis de esa fructífera relación, tanto en el ámbito anglosajón como en el europeo y sudamericano (y tanto desde la óptica de sus defensores como de sus detractores). Y son también importantes las utilidades metodológicas y analíticas que de esa relación se vienen señalando para una más profunda

\footnotetext{
1 Doctor em Filosofía por la Università di Roma (Italia) y Doctor em Derecho por la Universidad de Valencia (España). Profesor Titular de Filosofía del Derecho en la Universidad de Valencia (España).Valencia, España. E-mail: pedro.talavera@uv.es
} 
comprensión de las disciplinas jurídicas; en especial, para la filosofía del Derecho o la historia del Derecho².

La taxonomía de los modelos de relación Derecho-Literatura adquirió una formulación tripartita, casi canónica, a partir de la conocida obra de Richard Posner: Law and Literature: a Misunderstood Relation (1988) y su no menos famosa clasificación: Derecho como literatura, Derecho en la literatura y Derecho de la literatura; agudamente reformulada por Botero en seis modelos: retórico, expositivo, metodológico, analítico, jurídico y estético (Botero, 2008, p. 33-38). Y, específicamente, el recurso a la literatura como instrumento de reflexión crítica sobre el Derecho y los valores jurídicos se "popularizó" a partir de la emblemática obra de Martha Nussbaum: Poetic Justice: The Literary Imagination and Public Life (1995) y su apelación a la "imaginación literaria" como herramienta válida para "guiar a los jueces en sus juicios, a los legisladores en su tarea legislativa y a los políticos cuando midan las calidad de vida de gentes cercanas y lejanas" (Nussbaum, 1997, p. 27). Sobre esta misma senda han transitado también los importantes trabajos de François Ost (2004; 2005).

Sin embargo - y a pesar de ser escasamente citado en este ámbito ha sido Richard Rorty, con su decidida apuesta por el "giro narrativo" de la ética y la filosofía, quien más radicalmente ha situado a la literatura como herramienta crítica fundamental a la hora de reflexionar sobre los valores esenciales de la humanidad (Vásquez, 2006, p. 3-28). Rorty ha llegado aún más lejos que Nussbaum porque, cuando se trata de ahondar en los valores morales que sustentan la vida humana, otorga a la literatura - a la "imaginación literaria" - un valor superior al de la propia filosofía. La literatura, a su atinado entender, contribuye a ampliar la "capacidad de imaginación moral"; nos hace más sensibles, en la medida en que nos impulsa a profundizar en una comprensión empática sobre las personas y sobre sus necesidades reales (Rorty, 2002, p. 95-109). En efecto, las reflexiones filosóficas sobre la naturaleza humana no contribuyeron

\footnotetext{
2 Una panorámica general puede verse en: Talavera (2006, p. 5-6o). Más extensamente en: Karam y Magalhães (2009, p. 164-213). Desde una perspectiva metodológica puede verse el amplísimo estudio realizado por Calvo (2008, p. 3-28).
} 
demasiado a la eliminación de la esclavitud, al contrario del impacto conseguido por algunas narraciones literarias sobre la vida de los esclavos3.

Para Rorty el extraordinario valor de la literatura deriva de considerar el lenguaje como el instrumento fundamental para cambiar la realidad, ya que sostiene la existencia de una estrecha relación entre "léxicos" y "formas de vida"; de manera que sólo cuando se construyen "nuevos lenguajes" acaban surgiendo "nuevos modos" de vivir como seres humanos (Rorty, 1991, p. 52-61). No se trata, pues, de argumentar bien (filosofar) sino, sobre todo, de imaginar y narrar una forma diferente de vivir en el "mundo" (Rorty, 1991, cap. I). Cuando se plantean nuevas "formas de vida" a través de un lenguaje nuevo, acaban por surgir formas nuevas de conducta. Se trata de conseguir que un "nuevo léxico" triunfe, mostrando nuevos "modos de ser humano" y de organizar nuestra convivencia. No cabe establecer, pues, una frontera nítida entre la realidad y la ficción. De ahí que la reinvención del mundo (para Rorty) dependa, en última instancia, de la construcción de nuevas ficciones, puesto que los cambios sociales no se gestan tanto por el influjo del conocimiento sistemático (típico de la filosofía occidental), cuanto por el poderoso efecto de la imaginación (Rorty, 1991, p. 46-67). La literatura acaba convirtiéndose en un "género de investigación”, en un auténtico ejercicio práctico de construcción moral y política, precisamente porque en ella se verifica paradigmáticamente la capacidad de utilizar léxicos nuevos y de concebir un nuevo modo de vivir en la realidad 4 .

Este trabajo parte de la convicción, compartida con Rorty, de que la literatura tiene un enorme potencial transformador y contribuye decisivamente a la evolución de los modelos organizativos de la vida social:

3 Vid en este sentido las referencias a La Cabaña del tío Tom; Cartas Persas de Montesquieu, etc., (Talavera, 2006, p. 54-56). Rorty entiende, por ejemplo, que es en la literatura y no en la filosofía donde se encuentra la capacidad de concebir a los demás seres humanos como 'uno de los nuestros' y no como 'los otros', y de que podamos participar de sus experiencias concretas. Esa es la razón por la cual la novela, el cine y la televisión, poco a poco, pero ininterrumpidamente, han ido reemplazando al sermón doctrinal y al tratado filosófico como principales vehículos del cambio y del progreso moral (Vásquez, 2005, p. 8).

4 Como subraya Vásquez, para Rorty la filosofía es conservadora mientras que la poesía es radical y exploradora. Cuando los filósofos declaran: "Nosotros tenemos argumentos razonables, los poetas no los tienen", de hecho están diciendo: "Nosotros nos dedicamos a aquello que ya está sobre la mesa". Los poetas pueden replicar a ello: "Sí, pero nosotros, en ocasiones, ponemos algo nuevo sobre la mesa” (Vásquez, 2006, p. 327-328). 
"no vale la pena preocuparse tanto por fundamentar lo que se cree, vale más preocuparse por ser lo suficientemente imaginativo como para pensar alternativas interesantes a las propias creencias actuales" (Rorty, 1991, p. 32). No obstante, acudir a la literatura para imaginar un modo alternativo de convivir - como plantea Rorty - pasa necesariamente por buscar también en ella - como propone Nussbaum - el esclarecimiento de los valores esenciales sobre los que pretende fundarse nuestra convivencia (Nussbaum, 1997, p. 38). Eso es lo que he tratado de mostrar aquí, fijándome en uno de los pilares fundamentales sobre los que se asienta nuestra civilización: la idea de justicia y la reflexión que sobre ella y su compleja relación con el Derecho ha realizado la literatura, anticipando imaginativamente los nuevos modelos de organización social. Y pretendo mostrar cómo la literatura ha desarrollado ese potencial transformador en tres escenarios históricos, anticipando un cambio de paradigma en esta relación: la intuición clásica que propone superar el ámbito privado de la venganza y vincular la justicia al respeto de la ley; la concepción moderna, que fundamenta la justicia sobre principios éticos universales y la garantía de derechos y libertades; y la actual y progresiva disolución del concepto, bajo el influjo creciente del pensamiento nihilista postmoderno, de matriz nietzscheana, cuyo análisis niega la existencia de cualquier valor o fundamento objetivo, con la consiguiente pérdida de toda referencia moral (Vattimo, 1989, p. 23-31, 83-97; 1994, p. 10-24).

Me centraré para ello en el análisis de tres obras emblemáticas que representan, a mi juicio, el exponente de los tres grandes modelos de relación entre el Derecho y la Justicia, que han ido constituyendo los tres grandes ejes del vínculo social y la organización del Estado. Partiré de $L a$ Orestiada (Esquilo), construida en torno a la necesaria sustitución de los dioses viejos (los de la sangre y la venganza) por los dioses nuevos (la razón y el Derecho) para consolidar el modelo democrático de la polis. A continuación, en el contexto de la modernidad, analizaré en El mercader de Venecia la exigencia de que el Derecho sólo pueda ser expresión de la justicia si, más allá de la seguridad jurídica, garantiza el respeto a unos principios éticos universales inherentes al ser humano. Finalmente, guiados por la pluma maestra y profética de Dostoievski en Crimen y castigo, descubriremos la figura del "superhombre", que rechaza todo fundamento 
objetivo de la justicia y todo vínculo entre justicia y Derecho, tal y como preconiza hoy la postmodernidad decadente.

\section{LA ORESTIADA: EL DERECHO COMO FUNDAMENTO DEL ESTADO}

La Orestiada - obra compuesta por tres tragedias ${ }^{5}$ (Agamenón, Coéforas y Euménides $)^{6}-$, constituye un excepcional ejercicio de “imaginación literaria”, en el cual Esquilo plantea - en sintonía con Rorty la posibilidad de una sociedad alternativa (democrática) construida sobre un nuevo concepto de justicia (dikè) como superación del "dilema trágico" radicado en la venganza, en el paradigma de la "ley del talión"7.

Los poemas homéricos, anteriores a Esquilo, muestran la primitiva concepción ética de los griegos que se identifica con la figura del héroe, cuyo valor principal es la areté (el honor, la valentía y el éxito). Esto propiciaba un orden jurídico sustentado sobre una noción estrictamente retributiva de la justicia impartida por los dioses, que premian o castigan las acciones de los hombres. Es Hesíodo quien plantea un cambio fundamental en este esquema al resaltar, frente a los valores clásicos, la importancia de los valores de la vida cotidiana (los no propiamente "heroicos") como el trabajo. La vida virtuosa es, para Hesíodo, la del hombre que gana su sustento con esfuerzo y rectitud (Hesíodo, 1990, v. 87-100). Y es en este contexto donde comienza a plantearse la necesidad de defender al débil frente a la arbitrariedad del fuerte, y donde comienza a tomar cuerpo una idea de justicia (dikè) ligada al respeto de las leyes democráticas de la polis (nomos), indispensable para garantizar una conveniencia racionalmente organizada y pacífica (Herreras, 2008, p. 59-60).

Esquilo, aunque mantiene una continuidad con el pensamiento de Homero (valora el ideal clásico), da un paso adelante respecto a éste, desentrañando criterios objetivos que permiten diferenciar una sociedad justa de una injusta. No encontramos en su obra una definición acabada de

5 Sobre el sentido de la tragedia griega vid. Talavera (2006, p. 92-102).

6 Hemos utilizado la versión de Fernández-Galiano (2002).

7 Esquilo nació en los últimos años del siglo VI a.C. (año 524 a.C.) y sus obras abanderan la justificación teórica del nuevo orden democrático que culmina con la constitución de Clístenes (Rodríguez Adrados, 1998, p. 104). 
justicia, pero la percibimos muy ligada a la idea de armonía, de equilibrio, que surge de la contraposición filosófica entre caos (desorden provocado por la hybris) y cosmos (el "todo" armónicamente organizado). En efecto, en la mitología, dikè es hija de Zeus y Themis, del cielo y de la tierra (o sea, del "todo") y tiene como misión cuidar de que los hombres no cometan desórdenes. Como consecuencia, la justicia (la obra de dikè) consistirá fundamentalmente en controlar la hybris o restablecer el orden roto por su casusa, por la pasión descontrolada de los mortales. Esquilo propone aquí la superación del dilema trágico, mostrando que la dinámica de la venganza resulta insostenible como arquetipo de la justicia. Una sociedad que pretende progresar debe sustentarse sobre una nueva idea de justicia basada en el respeto a la ley y en la acción de los tribunales (Herreras, 2008, p. 61).

En la primera de las tragediass, Agamenón regresa victorioso de la guerra de Troya y es recibido en Argos por su esposa Clitemnestra que, ocultando su adulterio con Egisto, pronuncia discursos de queja por tan larga ausencia sin noticias, pero que anuncia grandes festejos. Agamenón trae consigo una esclava, Casandra, hija de Príamo (rey de Troya) que en un oráculo profético anuncia la tragedia que está a punto de consumarse en el palacio y que el coro completa recordando la maldición que pesa sobre los Átridas. Clitemnestra finalmente la consuma asesinando a Agamenón y a Casandra y justificando su venganza por el sacrificio de su hija Ifigenia, que Agamenón ofreció a los dioses para vencer en la guerra. Pero la venganza también es de Egisto, primo de Agamenón, que expone las atrocidades cometidas contra su padre, Tiestes, en el pasado. El coro de ancianos señala a Orestes como vengador de su padre y reclama la vieja "justicia de la sangre". Clitemnestra y Egisto se han "vengado", pero son conscientes de

8 La Orestiada, como decimos, plantea la superación del concepto exclusivamente vindicativo de la justicia, a partir de los sucesos sangrientos que mancharon la estirpe de los Tantálidas. Los hermanos Tiestes y Atreo, gobernadores de la ciudad de Micenas, se enemistan. Tiestes secuestra a la esposa de su hermano Atreo y este se venga con una acción horrible: mata a los hijos de aquel y en un banquete le presenta al padre como comida la carne de sus descendientes. Este crimen exige una nueva venganza de sangre por parte de Tiestes lo que genera una maldición que pesa sobre los Átridas. Esquilo da por conocida esta leyenda y en la primera de las tres tragedias representa el cumplimiento de esa venganza sobre Agamenón (hijo de Atreo), que ha sido tramada por Egisto (hijo de Tiestes), amante de Clitemnestra, esposa de Agamenón. 
que la cadena de muertes seguirá su curso ya que estas dos muertes son un eslabón más en la sangrienta historia de los Átridas.

En esta primera tragedia, la idea de la justicia se manifiesta bajo el tradicional principio retributivo-vindicativo: la areté (el honor, la valentía), en virtud del cual las obras honestas resultan premiadas mientras que las obras impías (hybris) generan la ruina de su autor y de su estirpe. Cuando el hombre deja de cumplir su obligación frente a dioses y hombres, incurre en injusticia, en adíkia, y debe ser aniquilado: "No hay defensa para el hombre que ahíto de riqueza derriba con el pie el gran altar de la Justicia: es su perdición”, anuncia el coro de Agamenón con solemnidad (Herreras, 2008, p. 59).

En efecto, con el rapto de Helena y el robo de los tesoros, Paris se ha portado de manera impía, transgrediendo la Xenía (ley de hospitalidad) y, como consecuencia de su doble culpa, doble ha sido su castigo: ha perdido a Helena y su casa y estirpe han sido destruidas. De acuerdo con la suprema justicia (dikè), la destrucción de Troya ha sido decretada por los dioses y Agamenón, comandante de los aqueos, ha sido el brazo ejecutor de esa justicia. Este mismo principio retributivo viene esgrimido por Clitemnestra contra su esposo Agamenón, responsable del sacrificio de la hija Ifigenia. Cuando las tropas aqueas se encuentran fondeadas en Áulide por el mal tiempo, el adivino Calcante vaticina la necesidad de sacrificar una virgen para calmar los vientos contrarios y la ira de Artemis. Agamenón decide sacrificar a su hija Ifigenia y con ello apacigua la ira de Artemis, pero desencadena la terrible venganza de Clitemnestra que la reina ejecutará a su regreso de Troya. El término griego "poinás”, utilizado por Casandra cuando vaticina que alguien en el palacio "cavila una venganza" (Ag., 1223), además de significar pena o castigo (las Poinai - las Furias - eran las diosas de la venganza y personificaban el castigo), en este contexto, incluye también los matices de reparación, compensación, expiación o satisfacción. Con esa misma palabra invoca Clitemnestra la reparación y satisfacción por el sacrificio de Ifigenia como justificación del asesinato de su esposo. Y ésa es también la expresión utilizada por Egisto cuando confirma que la muerte de Agamenón ha satisfecho la justicia exigida por el crimen cometido antaño por Atrio contra su padre Tiestes. En definitiva, la idea de justicia, como supremo decreto de los dioses, reúne una dimensión vindicativa - 
castigo - y una dimensión retributiva - reparación - (Stellino, 2007, p. 622).

No obstante, en el inexorable cumplimiento de este principio vindicativo retributivo, se descubre un extraordinario matiz diferencial entre la verdadera "justicia" (ejecución de la diké, como designio de los dioses) y la simple "venganza" (perseguir con ello otros fines impíos). En ese sentido, los Átridas son “águilas”, símbolo de la justicia divina de Zeus, pero son también "perros alados", puesto que abusan de su poder y se comportan, a su vez, de manera impía. Como consecuencia, la justicia divina (dikè) alcanza también a los aqueos, que son perseguidos por las negras Erinias (personificación femenina de la venganza), provocando que el regreso a su patria resulte funesto. Con ello, la tragedia se aparta del pensamiento agonal arcaico, al mostrar que el beneplácito divino (la justicia) no tiene por qué estar relacionado con el héroe, con el triunfador en la batalla (cuyos actos pueden desembocar en la hybris); y muestra también que el castigo de los dioses siempre recae en la impiedad (la injusticia) cualquiera que sea quien la cometa (Herreras, 2008, p. 62). Así pues, Agamenón invoca la justicia para destruir Troya, pero acaba dejándose arrastrar por la hybris y cometiendo graves injusticias como el brutal saqueo de Ilión, o el sacrificio de su propia hija Ifigenia ${ }^{\circ}$. Clitemnestra pretende actuar justamente como vengadora de su hija, pero lo que quiere en realidad es una injusticia: deshacerse de su esposo y continuar su adulterio con Egisto. Éste se presenta como vengador de su padre, pero lo que pretende es quedarse con la corona de Micenas y continuar las relaciones adúlteras con Clitemnestra. El coro (el pueblo) pretende justificarse alegando que en ausencia de Agamenón la ciudad se ha mantenido en paz, pero sabe bien que ha soportado cobardemente la usurpación de Egisto y su tiranía. En consecuencia, si el verdadero sentido

9 La victoria sobre Troya está muy lejos del glorioso triunfo de La Ilíada de Homero. Agamenón está ciego en su hýbris y se jacta del saqueo de Troya. El personaje trágico de Agamenón altera, clara y abiertamente, los ideales agonales provenientes de los tiempos de Homero. Lo que allí era gloria, honor, fama, saqueos y riquezas, aquí es impiedad o injusticia castigada (Herreras, 2008, p. 62).

${ }^{10}$ Precisamente, lo que reprocha el coro a Agamenón respecto a la muerte de su hija es que, en lugar de tener remordimientos por ese horrible crimen, se haya justificado y esté convencido de que actuó bien; "que haya pasado del horror a la complacencia" (Nussbaum, 1995, p. 85). 
de la justicia consiste en restablecer el orden roto por la hybris, por la pasión descontrolada de los mortales, aquí ninguno de los actores de la tragedia ha buscado la verdadera "justicia", sino satisfacer sus deseos impíos de "venganza", perpetuando con ello el desorden de la hybris.

La segunda parte de la trilogía, Las Coéforas, se abre con la invocación a Zeus por parte de Orestes, hijo de Agamenón y Clitemnestra, de poder vengar (teísasthai) la muerte de su padre. Paralelamente, Electra, hermana de Orestes, habla de su situación con el Coro de ancianas y éste le asegura que pronto aparecerá alguien (Orestes) que conoce a los culpables del asesinato de Agamenón y no los perdonará. Ante eso Electra formula una pregunta que muestra lo borroso de la frontera entre justicia y venganza pero que resulta esencial a la hora de delimitar los perfiles de ambas:

- Electra: ¿̇Te refieres acaso a un juez o a un vengador?

- Corifeo: No; di sólo alguien que dé muerte por muerte

- Electra: ¿Y que pida esto a los dioses / lo crees tú muy piadoso?

- Corifeo: ¿Y cómo no va a ser santo y piadoso / devolver mal por mal al enemigo? (Coéf., 120-123).

La Corifeo disuelve las dudas de Electra contestando que se trata, simplemente, dar "muerte por muerte". Ante lo cual, Electra manifiesta una repugnancia natural y pregunta (ingenuamente) si cabe pedir "venganza" (un nuevo asesinato) a los dioses. La Corifeo responde invocando la inexorabilidad de la "ley del talión": lo divino es devolver al enemigo mal por mal.

En la figura de Electra y sus dudas, Esquilo pretende mostrar que los ideales clásicos (entre ellos, la venganza como exigencia de la ley del talión) no proceden de la razón y la sabiduría (la divinidad), sino de "tradiciones ancestrales", que no son sino interpretaciones históricas y parciales que los hombres han hecho de los designios divinos y que, por ello, deben perfeccionarse. En efecto, para Electra existe una diferencia sustancial entre un juez y un vengador (de hecho no sabe si aparecerá uno u otro). Con ello parece manifestar que el cumplimiento de la justicia sólo puede venir de un juez (un tercero imparcial al que sólo mueve la ley divina) mientras que del vengador sólo puede esperarse otro "crimen" para la satisfacción de su "resentimiento", para saciar su odio. 
Pero en el diálogo de Electra con el Coro, Esquilo evidencia el enorme poder que todavía tiene la tradición en la moral social, hasta el punto de banalizar la distinción entre justicia y venganza, apelando exclusivamente al resultado inexorable del cumplimiento de cualquiera de ambas: la muerte del ofensor. Así pues, tanto el juez que imparte justicia como el vengador que honra a su padre asesinado, ejecutarán la misma acción. Orestes pretende vengar a su padre matando a su madre y, con ello, no hace sino dar cumplimiento a la Justicia divina que impone vengar el asesinato de un ser querido castigando con la muerte a sus autores. Al final de un largo discurrir consigo misma, Electra parece resignarse a aceptar la justicia del acto vengador que Orestes planea; tanto es así, que lo acaba pidiendo expresamente a los dioses:

- Electra: para mi enemigo / yo imploro, oh padre, que aparezca un día / quien te vengue, y que en justicia mueran / tus asesinos (Coéf., 144).

Es el Coro quien más se aferra a la concepción tradicional de la justicia (el talión) para legitimar la muerte de Clitemnestra y Egisto, invocando a las "Moiras", hijas de la Noche y personificación del destino, para que, de parte de Zeus, se cumpla "lo justo":

- Corifeo: iQue las palabras de odio sean pagadas con palabras de odio!, / lo clama a voces Justicia (Dikè) exigiendo su deuda. / iQue todo golpe mortal sea castigado con otro golpe mortal! / iQue sufra quien lo hizo! -clama un proverbio tres veces viejo (Coéf., 310314).

En definitiva, aunque Orestes actúe movido por el odio y el resentimiento, y aunque la víctima de su crimen sea su propia madre, su venganza viene considerada como el inexorable cumplimiento de la justicia. Así lo manifiesta en su petición a Zeus: “iOh Zeus! iOh Zeus!, Envía / desde abajo un tardío / castigo contra la madre osada y asesina / iIncluso en una madre ha de cumplirse!” (Coéf., 380-385). Y así lo asume tras perpetrar el crimen: "en justicia ejecuté a mi madre" (Coéf., 990).

Tras el matricidio consumado por Orestes, Esquilo introduce dos elementos trascendentales a partir de los cuales se inicia el proceso de superación del dilema trágico: en primer lugar, aparecen las Erinias de la familia que, vestidas de negro y con serpientes en la cabeza, quieren vengar la muerte de Clitemnestra (continuando así con la cadena infinita de 
venganzas); $\mathrm{y}$, en segundo lugar, la supuesta locura que sobreviene a Orestes desde el momento en que se da realmente cuenta de lo que ha hecho: ha asesinado a su propia madre. Con la aparición de las Erinias, a Orestes no le queda otro remedio para salvar su vida que acudir como suplicante al tempo de Apolo en Delfos, marcando con ello el paso de la segunda a la tercera parte de la trilogía (Las Euménides). Con el proceso de introspección de Orestes aparece en escena la realidad de la culpa, del remordimiento (en sintonía con lo que luego veremos en el personaje de Raskolnikov) y, con ello, la posibilidad de establecer una diferencia moral entre el justiciero y el vengador.

En efecto, la tercera tragedia (Las Euménides) se centra en determinar la justicia o injusticia del matricidio de Orestes a través de las distintas posiciones que sustentan al respecto las Erinias y Apolo. Por una parte, las Erinias exigen que Orestes pague por la muerte de su madre:

- Erinias: iAy! iAy! Hijo de Zeus [se refiere a Apolo, protector divino de Orestes, al que éste se encomienda para llevar a cabo la venganza] / ¿quién podrá sostener que esto es justicia? / [...] Ha ensuciado su morada / por un impulso propio, / no invitado por nadie. / Ha honrado a los mortales transgrediendo / las leyes de los dioses (Eum., 150-155).

Apolo, sin embargo, justifica el crimen arguyendo que fue él mismo quien ordenó a Orestes que vengara la muerte de su padre. Comienza a vislumbrarse aquí la sutil distinción entre el vengador - el que ha obrado por impulso propio para honrar a un mortal -, y las justicieras - que defienden el cumplimiento de las leyes de los dioses (diké). Para dirimir la cuestión, acuden a la Acrópolis para que sea un juez imparcial, Atenea, quien emita un veredicto definitivo. Las Erinias manifiestan frente a la diosa ser "rectas justicieras" (Eum., 312). Afirman que no están movidas por la cólera o el odio, sino que sólo pretenden ser "ejecutoras de una deuda de sangre” (Eum., 320) que dimana del matricidio llevado a cabo por Orestes. Éste, a su vez, explica a Atenea que su acción respondió al horrible crimen cometido por su madre, que asesinó a su padre de forma ignominiosa cuando regresó vencedor de Troya. Y, a continuación, se acoge a su autoridad para que sea ella quien determine "si fue con justicia o no" (Eum., 468). 
Como la cuestión resulta compleja, Atenea decide convocar un tribunal en el Areópago, compuesto por doce jueces y ella misma ${ }^{11}$. Durante el transcurso del juicio, Las Erinias arguyen que el crimen de Orestes es peor que el de Clitemnestra, ya que ésta mató a quien no era de su sangre: y “¿dónde hay un aguijón tan grande como para matar a una madre?” (Eum., 427). Apolo arguye que las madres no son realmente progenitoras sino únicamente depositarias de la semilla de vida del padre, como demuestra el hecho de que Atenea naciera de la cabeza de Zeus. Tras un arduo debate queda patente que las Erinias, aunque se definieron a sí mismas como "justicieras", en realidad demuestran ser también simples "vengadoras" puesto que sólo les interesa ejecutar la exigencia ancestral de vengar el matricidio y no atienden a las circunstancias que ahí concurren. A partir de este momento resulta evidente que el afán de venganza estaba presente tanto Orestes como las Erinias, por lo que resulta difícil establecer de qué parte está la verdadera justicia. Tan compleja resulta la cuestión que el escrutinio de los doce jueces resulta paritario (mitad a favor de cada parte) y debe ser Atenea la que decida finalmente. Las Erinias advierten a Atenea que si en su decisión no respeta la ley divina (la de los dioses antiguos) se promoverá la impunidad de quienes cometan crímenes similares (parricidio) y se instaurará el caos:

- Erinias: Hoy habrá subversión, hoy nuevas leyes, / si triunfa el derecho / asesino de este matricida. / A todos los mortales / esta hazaña ha de abrirles / la ruta a la licencia. / ¿Qué heridas abiertas por sus hijos / aguardan a los padres, con el tiempo? [...] pues se ha hundido el hogar de la Justicia (Eum., 510-519).

Atenea decide el destino de Orestes absolviéndolo de su crimen (rompiendo con ello la ancestral cadena de venganzas) y permitiéndole volver a su casa después de haber jurado su alianza al pueblo de Atenas. Con ello Atenea se pone de parte de los hombres, frente al pasado en que éstos eran meros instrumentos de la arbitraria voluntad de los dioses, y abre el camino para establecer un nuevo marco de convivencia. Un nuevo

\footnotetext{
11 Tanto el contraste de pareceres entre las Erinias y Apolo como el nombramiento de un tribunal en el Areópago para dirimir el pleito, manifiestan la tensión existente entre los dioses antiguos (las Erinias) y las tradiciones arcaicas (la ley del talión), frente a los nuevos dioses olímpicos (Atenea) que garantizan y respaldan la organización democrática y las leyes de la polis (Rodríguez Adrados, 1998, p. 69-70).
} 
orden social fundamentado sobre la constitución de un tribunal "justo e insobornable" que permanezca para siempre (Eum., 705). El veredicto de Atenea significa, pues, la evolución desde lo primitivo hacia lo civilizado, desde lo ancestral hacia lo racional, desde la concepción gentilicia hacia lo propiamente político. Solo así será posible la prosperidad ciudadana, el orden y la paz. Un paso, en definitiva, que constituye la matriz de lo que hoy denominamos Estado de derecho, es decir, la consagración del Derecho como fundamento del Estado, el establecimiento de leyes democráticas que determinen la frontera de lo lícito e ilícito y la existencia de jueces que garanticen una dimensión pública y objetiva de la justicia, excluyendo la legitimidad del ejercicio privado de la venganza (Herreras, 2008, p. 64).

Las Erinias, heridas en su orgullo y llenas de rencor, acusan a los "jóvenes dioses" de haber pisoteado con esa sentencia las leyes ancestrales y prometen arrojar de su corazón veneno sobre la tierra, el veneno causado por la ira, el rencor y el resentimiento (kótos) que caracteriza la venganza de estas "viejas diosas" en toda la trilogía. Atenea intenta convencer a las Erinias de que la suya no ha sido una derrota, sino que la sentencia se ha resuelto a favor de la verdad y, a cambio de reprimir su ira, les promete que serán honradas por los hombres y poseerán, de pleno derecho, una sede en esa tierra. Así pues, convencidas por Atenea, las Erinias deciden deponer su negro resentimiento - "methistamai kótou" (Eum., 900) - y aceptan la nueva misión que la diosa les asigna: proteger la tierra, a los animales y a los ciudadanos. La metamorfosis de las antiguas diosas se ha cumplido: las Erinias (vengativas y rencorosas) se han convertido en Euménides, "benévolas" (Eum., 992), "honorables" (Eum., 1033) y "augustas" (Eum., 1041).

En los últimos versos de Las Euménides se hace patente una polaridad entre las Erinias, diosas antiguas, símbolos de una primitiva forma de justicia, y los jóvenes dioses, "defensores de la nueva idea democrática acerca de la ley" (Stellino, 2007, p. 626). Con ello, Esquilo pretende acercar la idea de justicia (dikè) al cumplimiento de la ley humana (nomos) más que al dictado de las tradiciones ancestrales (el talión), sin prescindir del fundamento divino que vincula a la justicia con una dimensión universal de orden y armonía del cosmos (Rodríguez Adrados, 1998, p. 150-154). En consecuencia, lo que distingue a un justiciero (Orestes) de un vengador 
(Erinias, Clitemnestra) radica fundamentalmente en que su actuación no sea arbitraria (fruto de la hybris), sino que sea ajustada al nomos, a la ley dictada por el pueblo soberano (demos). En ese sentido, la justicia del veredicto emitido por Atenea, apartándose de la tradición ancestral, radica en la legitimidad del tercero imparcial, que actúa representando al pueblo y que está por encima del designio particular de cualquier individuo. Esquilo apunta, pues, a la ineludible dimensión formal de la justicia, como límite o garantía de que su ejecución responda a la razón pública y no sucumba al desafuero privado de la hybris. Por eso, el veredicto exculpatorio de Atenea sobre Orestes legitima la acción homicida de éste en tanto que reviste una cierta dimensión pública (ejecución de un castigo justo), al haber sido ordenada por Apolo y en atención a lo execrable del acto de Clitemnestra. Pero, con ello, Esquilo - siempre respetuoso de la tradición - deja abierta la puerta a que la venganza privada pueda resultar legítima cuando se satisface en el marco del nomos, o incluso que el propio nomos pueda responder a designios vengativos. He ahí el punto de conexión con la figura de Shylock en El mercader de Venecia, y su pretensión de utilizar la ley como instrumento para saciar su sed de venganza.

En consecuencia, cabe plantearse una última cuestión: ¿Qué ha primado en Orestes la justicia o el resentimiento? La respuesta podemos encontrarla en el lenguaje utilizado por el Corifeo para establecer una relación entre ambas:

Ha guiado su mano en la batalla la auténtica / hija de Zeus - "iJusticia!" la / Llamamos los mortales con razón / respirando rencor fatal contra sus enemigos (Coéf., 948-952).

Esquilo concibe la posibilidad de que la justicia pueda triunfar aun en medio de un océano de odio y resentimiento. Por eso, el Corifeo afirma que ha sido la Justicia quien ha guiado la mano de Orestes y no su odio: de ahí que haya sufrido la tortura y enajenación de los remordimientos, porque no era la satisfacción de la venganza la que le impulsó (Stellino, 2007, p. 627). Ese es el fundamento de la legitimidad de su acción: que está en sintonía con una razón pública, el castigo de un delito, y no con una pasión privada, la satisfacción de la venganza. En consecuencia, siempre que prevalece la razón pública (el respeto a la ley) prevalecerá la justicia, aunque quien 
ejecute el castigo o lo presencie pueda albergar interna o externamente resentimiento y deseos de venganza.

Para Esquilo, en efecto, la justicia reviste siempre un carácter público, relacional, intersubjetivo, de ahí la necesidad de su adecuación a la razón y al nomos; mientras que la venganza nace de un afecto que radica en el animus del individuo, por eso reviste siempre un carácter privado, subjetivo, emocional, no limitado y ordenado por la razón sino desbocado y desequilibrado por la pasión, por la hybris. Esquilo lo plasma magistralmente en el proceso de conversión de la Erinias (vengativas) en Euménides (protectoras del pueblo). La razón fundamental que provoca este cambio es la deposición del resentimiento por parte de las antiguas diosas y la asunción de su nuevo papel como protectoras de la ciudad. Es decir, la subordinación de las pasiones privadas al bien público de la polis. De ahí que, para Esquilo, el concepto de justicia (dikè) en el que debe basarse ese nuevo modelo democrático de sociedad pasa por el primado de la razón, manifestado en el respeto a la ley (nomos) que conduce a la paz y al orden, frente al predominio de la pasión (hybris) que conduce a la venganza, fruto del resentimiento. En otras palabras, prevalencia de la ley general sobre el interés privado como germen del Estado de Derecho.

En definitiva, para poner fin a los efectos perversos del resentimiento (la hybris) la sociedad establece la ley (el nomos), haciendo prevalecer con ella la justicia sobre la venganza, la razón pública sobre la pasión privada. De este modo, los delitos y su reparación dejan de tener un cariz exclusivamente subjetivo y privado (ofensa contra el perjudicado que éste debe vengar) y pasan a tener una fundamental dimensión pública y objetiva (vulneración de la ley que la justicia se encarga de reparar). He ahí el sentido más profundo de la ya mencionada conversión de las Erinias en Euménides.

Una última cuestión cabe suscitar sobre la trascendental aportación literaria de Esquilo al nuevo modelo de Estado democrático basado en la primacía de la ley (como expresión de la razón pública) sobre el interés privado. Y se trata, como es bien sabido, del problema del fundamento de la obediencia a la ley (fundamentación última del Derecho), suscitada años después por Sófocles en Antígona, cuando ésta se niega a someterse al Edicto de Creonte, invocando unos principios superiores de justicia que 
ninguna ley puede socavar. La referencia a los dioses como fundamento último de la ley está presente en Esquilo, pero su reflexión literaria apunta, sobre todo, a un concepto de justicia que se fundamenta en el respaldo democrático de la ley, como condición de posibilidad del Estado. Sin embargo, Sófocles, en el famoso diálogo entre Antígona y Creonte, va mucho más allá y se plantea el problema de fondo: ¿̇la obediencia a la ley se fundamenta en el consenso democrático que hace posible el Estado o en su referencia a principios morales universales? He ahí las dos posiciones (eternamente enfrentadas) que representan Creonte y Antígona: o bien la norma democrática (nomos) se presume justa (prohibición de enterrar al traidor); o bien la justicia (diké) radica en respetar un absoluto moral (mandato divino) que debe ser el fundamento de toda ley (nadie merece ser privado de sepultura y ser comido por los perros):

- Creonte: ¿Y a pesar de ello, te atreviste a transgredir estos decretos?

- Antígona: No fue Zeus el que los ha mandado, ni la Justicia (themis) [...]. No pensaba que tus proclamas tuvieran tanto poder como para que un mortal pudiera transgredir las leyes no escritas e inquebrantables de los dioses (Antígona, v. 448-451).

No procede tratar ahora la tensión existente entre lo "justo legal” y lo "justo moral", desarrollada poco tiempo después por Aristóteles, ni tampoco pretendo abordar aquí las profundas implicaciones que suscita la "imaginación literaria" de Sófocles. Tan sólo he querido servirme de Antígona para evidenciar que el problema (dilema trágico) del fundamento último del Derecho queda abierto en la reflexión literaria clásica (Antígona no lo resuelve ${ }^{12}$ ) y viene retomado por Shakespeare en el Mercader de Venencia, como veremos a continuación, a través del planteamiento de un nuevo "dilema trágico" entre moralidad y legalidad, que la figura de Portia sí resuelve integrando la moralidad en la legalidad.

\footnotetext{
${ }^{12}$ Me he ocupado extensamente del conflicto de Antígona en: Talavera , 2006, p. 105-130.
} 


\section{EL MERCADER DE VENECIA:}

\section{EL FUNDAMENTO MORAL DEL ESTADO DE DERECHO}

El judío Shylock, protagonista de la inmortal obra El mercader de Venecia, escrita por Shakespeare alrededor de $1594^{13}$, es una de las figuras más emblemáticas de la literatura. La disputa judicial entre Shylock y Portia ante el Dux de Venencia (eco de la disputa entre Atenea y la Erinias en el Areópago) constituye otra pieza maestra de esa "imaginación literaria" aludida por Rorty y Nussbaum, en la que se hace patente la imposibilidad de reducir la justicia al estricto cumplimiento de la legalidad (dimensión meramente procedimental). Shakespeare propone aquí una idea de justicia ineludiblemente vinculada a la salvaguarda de aquellos valores morales que nos constituyen como humanos y que jamás pueden vulnerarse a la hora de aplicar lo estipulado en la ley ${ }^{14}$.

Más allá de las tramas románticas y de los personajes tópicos (exigidos por el público de la época) ${ }^{15}$, la obra se desarrolla en torno a dos sentimientos humanos radicalmente opuestos: el amor y la amistad (representados por Antonio, Bassanio y Portia) frente al odio y al resentimiento (representados por la figura de Shylock). Ambas líneas representan, a su vez, dos modos radicalmente opuestos de concebir el Derecho: bien como expresión de valores morales fundamentales (la justicia); o bien, como instrumento neutro que puede ser cauce de cualquier interés, incluida la venganza. La imaginativa trama judicial, que enfrenta estas dos posiciones, nos sitúa ante el "dilema trágico" planteado por la compleja relación entre moralidad y legalidad: ¿puede la ley legitimar la ejecución de un crimen atroz, de una injusticia manifiesta? ¿Se puede hacer justicia ejecutando legalmente una venganza?

La historia arranca con el deseo de Bassanio de casarse con Portia, la bella y rica heredera de Belmonte. Para ello pide prestados tres mil ducados a su mejor amigo: el mercader Antonio. Careciendo de ese dinero en efectivo, Antonio se ofrece como fiador de Bassanio ante Shylock, un

\footnotetext{
${ }^{13}$ La traducción que utilizo en este comentario es la de Valverde, 2003.

14 Shakespeare aborda también esta cuestión en otra obra menor, de argumento similar: Medida por medida, escrita entre 1607 y 1608.

15 Para más detalles sobre aspectos técnico literarios de la obra, vid: Valverde, 2003, p. XXXVII.
} 
usurero judío, despreciado y ridiculizado por Antonio en diversas ocasiones, pero que accede a conceder el préstamo (sin intereses, como los cristianos dicen que debe hacerse) estipulando que si el dinero no le es devuelto en tres meses podrá cortar una libra de carne de la parte que le plazca del cuerpo de Antonio. El contrato se formaliza ante notario y Bassanio parte en rumbo hacia Belmonte. Allí logra su objetivo y, una vez concertada la boda entre ambos, recibe un mensaje de Antonio pidiéndole que regrese a Venencia para acompañarle en su última hora, puesto que sus barcos no han llegado y no puede hacer frente a la deuda adquirida con Shylock. Bassanio, ahora ya rico, vuelve a Venecia, en la que Shylock, movido por el odio y resentimiento hacia Antonio, reclama insistentemente al Dux, suprema autoridad judicial, que ejecute lo pactado en el contrato tal y como en justicia le corresponde; de lo contrario - amenaza - todo el orbe sabrá que en Venecia no se respetan las leyes, y su poderío y su fama caerán en picado, porque nadie más arriesgará allí sus bienes, ante el temor de perderlos impunemente.

El Dux se encuentra ante una grave disyuntiva: no quiere sancionar la horrible muerte de Antonio, pero tampoco puede arriesgar el bienestar de Venecia basado en su implacable cumplimiento de las leyes (seguridad jurídica). Aquí es donde da comienzo la trama judicial de la obra. Bassanio trata de convencer a Shylock para que acepte tres veces la suma pactada y desista de su pretensión de cortar "una libra de carne" del cuerpo de Antonio, pero aquél, cegado por el odio, exige lo estipulado en el contrato. El Dux pide la presencia del doctor Baltasar (que es en realidad Portia disfrazada de hombre) para que le asista en la interpretación de las leyes de Venecia. El doctor Baltasar (Portia), tras plantear diversas soluciones y apelar inútilmente a una justicia que está más allá de la ley, da la razón a Shylock y admite que el contrato debe cumplirse y que el judío puede ejecutar la cláusula penal. No obstante, realizando una hábil interpretación, afirma que si la carne cortada no pesa exactamente una libra, o si se derrama una sola gota de sangre, será condenado por homicida, ya que ni la sangre ni la vida de Antonio estaban estipuladas en el contrato. Ante tan inesperada interpretación legal (“¿es ésa la ley”, pregunta desconcertado), Shylock pretende aceptar las contraprestaciones que se le habían ofrecido previamente; pero ya es tarde, porque Portia recuerda también que la ley 
veneciana castiga a quienes "hubieran atentado, directa o indirectamente, contra la vida de un ciudadano de Venecia”. Entonces Antonio se muestra compasivo y pide indulgencia para Shylock. El Dux le perdona la horca a condición de que se convierta al cristianismo y legue sus bienes a su hija Jessica. Shylock acepta y la obra termina dejando en el lector la sensación de que la justicia ha prevalecido.

A pesar de que Shakespeare alaba la grandeza moral de la "compasión" (virtud de los cristianos) que acaba prevaleciendo sobre el deseo de "venganza" (pretendida por el judío), la figura de Shylock no resulta bufonesca sino trágica. Shylock no responde al estereotipo de un judío mezquino, avaro y cruel, sino al de un auténtico héroe trágico: un hombre humillado, vejado y excluido; roto por el abandono de su propia hija y sumido en un resentimiento de raíces milenarias, no justificable pero comprensible. No estamos, pues, ante un individuo despreciable y sin escrúpulos, sino ante una persona llena de los sentimientos humanos más profundos, que sustenta una concepción retributiva y vindicativa de la justicia (el talión) cuyo fundamento está más allá de su credo religioso: la considera una realidad inscrita en la propia naturaleza del ser humano. De ahí que denuncie la profunda hipocresía de los alegatos a la caridad, la compasión o la misericordia, que formalmente regulan la sociedad cristiana. La ironía con que Shylock recibe la petición de dinero de Antonio resulta paradigmática al respecto (Escena III, Acto Primero)

Pero Shylock va más allá de la ironía y denuncia expresamente la hipocresía de quienes se consideran moralmente superiores a él por profesar los valores cristianos (traducción de la justicia como misericordia o clemencia) y manifiesta sin ambages que sólo cabe hablar de justicia allí donde se verifica la reciprocidad. Y es así como entiende la venganza, como una estricta simetría (el talión), como la expresión más perfecta de la justicia. La venganza, pues, nace de un sentimiento profundo del individuo ofendido, pero no por su inferioridad o bajeza moral, sino como consecuencia del innato sentido de la justicia que todo individuo alberga en su interior. La venganza responde a una sed emotiva de justicia. Prueba de ello es que también los cristianos (más allá de su hipocresía) buscan la venganza para satisfacer sus exigencias de justicia. En efecto, los cristianos hablan de piedad, pero luchan a muerte contra sus enemigos y ejecutan 
públicamente a los herejes; hablan de generosidad pero castigan a sus esclavos y encarcelan a los deudores... Por eso Shylock considera justificado su deseo de venganza contra Antonio, porque responde, en estricta reciprocidad, a las vejaciones y humillaciones a las que éste (y los demás cristianos) le han sometido. Así lo expresa, de manera magistral, en uno de los pasajes más memorables de la obra:

(Salarino): "Si no cumple, estoy seguro de que no querrás su carne: ¿para qué te sirve?”

(Shylock): "Para cebo de pesca. Si no alimenta otra cosa, alimentará mi venganza. Me ha denigrado y me ha hecho perder medio millón; se ha reído de mis pérdidas, se ha burlado de mis ganancias, ha insultado a mi raza, ha estropeado mis tratos, ha enfriado a mis amigos y ha acalorado a mis enemigos: y ¿cuál es su motivo? Que soy judío. ¿No tiene ojos el judío? ¿No tiene el judío manos, órganos, miembros, sentidos, emociones, pasiones? ¿No se alimenta de la misma comida, no se lastima con las mismas armas, no se expone a las mismas enfermedades, no se cura con los mismos remedios, no se calienta con el mismo verano y se enfría con el mismo invierno que el cristiano? ¿Si nos hacéis un corte, no sangramos? ¿Si nos hacéis cosquillas, no reímos? ¿Si nos ponéis veneno, no morimos? ¿Y si nos hacéis un agravio, no habremos de vengarnos? Si somos iguales a vosotros en lo demás, también en eso hemos de parecernos. Si un judío agravia a un cristiano, qué mansedumbre muestra éste? La venganza. Si un cristiano agravia a un judío, ¿cual tendría que ser su resignación, a ejemplo del cristiano? Pues la venganza. La infamia que me enseñáis la pondré en ejecución, y mal habrá de irme para que no mejore la instrucción" (Escena I, Acto Tercero).

Shylock es un hombre resentido y el resentimiento (como ya nos mostró La Orestiada) es el fundamento del deseo de venganza. En esa misma línea se sitúa Nietzsche cuando aborda el origen de la justicia en su obra $L a$ genealogía de la moral. En el tratado segundo ("Culpa, mala conciencia y similares") habla de la venganza como un sentimiento primitivo, motivado por la imposición social de "recordar" determinados presupuestos fundamentales para la convivencia social y describe las más crueles torturas que se han practicado a lo largo de la historia (Nietzsche, 2006, II, n. 3). La venganza, para Nietzsche, radica en identificar los conceptos de "culpa" y "deuda" (el deudor es además culpable de una ofensa); en consecuencia, se piensa que "todo debe y puede ser pagado"; es decir, que todo perjuicio puede y debe tener una compensación material (reparar el daño) y moral (reparar la ofensa). De ahí que la justicia consista en garantizar esa doble reparación 
(Nietszche, 2006, II, n. 4). Este es el importante matiz que Nietzsche observa en la idea tradicional de justicia: que la exigencia de "pagar la deuda" va más allá de la estricta compensación material e incluye, fundamentalmente, una reparación "afectiva" de la culpa (el bienestar ante sufrimiento del deudor). Y ese es el espacio para la satisfacción de la venganza (Nietzsche, 2006, II, n.5).

Pero Nietzsche critica agriamente a los autores (como Düring) que incluyen la satisfacción afectiva del resentimiento (la venganza) en el origen de la justicia (Nietzsche, 2006, II, n. 11). Para él la justicia es un privilegio del "hombre fuerte"; es decir, de quien no permite que el resentimiento perjudique su objetividad a la hora de juzgar. Por ello, la justicia acaba precisamente donde el "veneno del resentimiento" infecta la razón y sólo deja espacio a la venganza, un afecto (resentimiento) que es propio del "hombre débil" (inferior), que sólo puede saciarse con otro afecto: el bienestar producido por el sufrimiento del ofensor. En el deseo de venganza, sólo existe para Nietzsche un sentimiento "reactivo" (cuyo valor biológico es muy bajo); por el contrario, la justicia sólo puede encontrarse en el terreno de los afectos auténticamente "activos" (cuyo valor biológico es más alto). En consecuencia, ser justo supone siempre un comportamiento positivo, puesto que la justicia debe imperar incluso con aquellos que nos han perjudicado. Son necesarias mucha fuerza y nobleza características propias del hombre "activo" - para poder ser justo con quien nos ofende (Nietzsche, 2006, II, n. 11).

La figura de Shylock constituye el exponente de quienes consideran que la "satisfacción afectiva" del resentimiento es inherente al deseo natural de justicia. De ahí que la venganza (la dimensión vindicativa) constituya para él un ingrediente básico de la justicia (la dimensión afectiva de la reparación por el perjuicio causado). En efecto, Shylock, que ha sido continuamente despreciado y humillado por Antonio, pretende vengarse de él no arrastrado por la obcecación del sanguinario, sino invocando el concurso de la ley para ejecutar la más estricta justicia. El contrato suscrito por ambos es para Shylock la plasmación más perfecta de su concepción de lo justo; y ejecutar lo estipulado en el contrato (cortarle una libra de su carne) supone mostrar a Antonio la trascendencia moral que reviste un perjuicio (la deuda material es, además y sobre todo, una ofensa moral que exige reparación afectiva). Precisamente por eso, Shylock no entiende que 
se le pida compasión. No concibe la verdadera justicia al margen de la "satisfacción afectiva" que proporciona la venganza. Es lo que Shylock parece decir a todos en el juicio ante el Dux: lo que yo busco, cobertura legal para desollar vivo a uno de vuestros respetados y ricos ciudadanos, responde al sentido más profundo y genuino de la justicia: más allá de la compensación material (dimensión retributiva) está la satisfacción afectiva de infringir a otro un sufrimiento paralelo al perjuicio causado (dimensión vindicativa). Y la prueba fehaciente de ello es que vosotros, cristianos que predicáis la misericordia, desearíais desollarme vivo a mí si os brindara la ocasión para llevarme delante de un tribunal.

Pero, como he apuntado, Shylock no es un anarquista sanguinario; al contrario, es un estricto formalista, por ello reconoce el necesario concurso de la legalidad para mantener el orden social (acude a un juez e invoca las leyes de Venecia), pero sólo concibe como justa esa legalidad en la medida en que se acerca al "talión"; es decir, en la medida en que incluye esa doble dimensión, retributiva y vindicativa, y se restaura el equilibrio, tanto material como afectivo, que la ofensa rompió. En la lógica de Shylock, sentimientos como la compasión, la clemencia o la misericordia, son sólo un ropaje hipócrita, absolutamente ajeno a la idea natural de justicia. En efecto, cuando se ha sufrido una ofensa y aparece el resentimiento que alimenta el deseo de venganza (de restaurar el equilibrio), no son la misericordia o el perdón quienes pueden restaurar ese equilibrio, solamente la estricta reciprocidad del "talión" permite realizarlo, porque no puede existir una idea más perfecta de justicia que la basada en una estricta reciprocidad. Precisamente por eso, la perfecta reciprocidad de la justicia no puede reducirse a una dimensión retributiva (reciprocidad material, “ $d o$ ut des"), necesariamente debe incluir también, en su caso, una reciprocidad afectiva frente al perjuicio padecido (vertiente punitiva; "ojo por ojo"). La venganza, pues, lejos de aparecer como una aberración, se impone aquí como un sentimiento natural, como una componente ineludible de la justicia, pero que debe ser garantizado (para evitar una nueva desmesura) por el concurso de la legalidad y del juez. Por eso Shylock asume la "dimensión pública" del "talión"; es decir, la exigencia formal de que la justicia (retributiva y vindicativa) se manifieste a través de la legalidad, excluyendo así el desequilibrio y el desorden propio de la venganza privada. 
En otras palabas, el concurso de la legalidad, el amparo público de la ley, no puede ser un obstáculo para vengar sus agravios, para satisfacer afectivamente las ofensas sufridas.

Es en este punto donde se plantea la verdadera batalla conceptual y donde se aprecian las opuestas concepciones de la justicia que sustentan cada uno de los protagonistas. Para Shylock sólo cabe hablar de justicia cuando la ley asume las exigencias retributivas y vindicativas (dura lex sed lex); por tanto, la cláusula penal del contrato debe ejecutarse una vez constatado su incumplimiento. Por el contrario, para Antonio y Bassanio la justicia se concibe desde una perspectiva "utilitarista" que se resuelve en una mera cuestión "indemnizatoria": triplicar el monto de la deuda (¿para qué le sirve al acreedor una libra de carne?). Por su parte, el Dux sustenta una concepción "política" de la justicia: encontrar el modo de salvar la vida de un ciudadano importante de Venencia (además de amigo y cristiano) sin comprometer con ello su reputación de juez incorruptible. Pero el verdadero contrincante intelectual de Shylock es Portia (disfrazada de Baltasar) que representa una concepción integral de la justicia, que reconoce el valor de la reciprocidad del "talión”, pero pretende ir más allá, mostrando sus límites y apuntando hacia el fundamento último de la legitimidad del Derecho: la defensa de los valores y principios morales básicos que nos constituyen como humanidad.

Portia, en efecto, acepta la validez de lo estipulado en el contrato y así lo proclama en el juicio: "no hay poder en Venecia que pueda alterar un decreto establecido. Se anotaría como precedente y muchos abusos invadirían el Estado". La legalidad es el marco dentro del cual se debe encontrar la justa solución al conflicto entre lo estipulado en el contrato (cortar una libra de carne humana) y la exigencia moral de evitar la tortura y salvar la vida de un ser humano. Para ello, Portia solicita del acreedor, en primer lugar, un gesto de humanidad (la clemencia), pero sin cuestionar el principio básico de reciprocidad: pide no ejecutar el contenido punitivo de la cláusula y aceptar una generosa contraprestación: “Tened clemencia; tomad el triple del dinero y dejadme romper el documento" (Escena I, Acto Cuarto).

Ahora bien, para Portia, introducir este valor (la clemencia) como componente de la justicia en este caso, no procede de un mero sentimiento compasivo frente al deudor, sino de la constatación de que identificar la 
justicia con una estricta reciprocidad (el talión) resultaría insostenible para una convivencia realmente humana en la sociedad, como luego demuestra con su astucia procesal e interpretativa. A lo que Portia está apelando, en definitiva, es a la equidad, haciéndose eco del clásico aforismo: summun ius summa iniuria:

Así pues, judío, aunque sea la justicia lo que pretendes, considera que en la aplicación estricta de la justicia ninguno de nosotros obtendría la salvación... (Escena I, Acto Cuarto).

Pero Shylock, como vimos, no puede concebir la clemencia o la misericordia como componentes de la justicia, por eso ni siquiera las invoca para salvar su propia vida cuando Portia le acusa de intento de homicidio. Aunque tampoco pretende, ni justifica, una violencia desbocada fruto de la ejecución privada de la venganza, porque también rompería el principio de estricta reciprocidad. De ahí que el "talión" represente para él el supremo y justo equilibrio que ha de ser respetado: al incumplimiento de lo pactado corresponde la estricta ejecución de la cláusula penal (cortar una libra de carne del cuerpo de Antonio). Portia acepta la exigencia de Shylock de atenerse al documento (carne por incumplimiento) y así lo hace saber a Antonio, en la cumbre del clímax dramático de la escena:

Pues entonces debéis preparar el pecho para el cuchillo... Pues la intención y el sentido de la ley está de acuerdo con la penalidad que aparece debida en el documento (Escena I, Acto Cuarto).

No obstante, el momento decisivo se produce cuando Shylock abandona la rigurosa objetividad de su posición en el ámbito público (estricta reciprocidad) y cede ante sus impulsos de perseguir, ante todo, una venganza privada (demostrando con ello la dificultad, a la que aludía Nietzsche, de ser justo cuando media el odio y el resentimiento). En efecto, Shylock se opone a la petición de Portia de solicitar la presencia de un médico, para evitar que Antonio pueda morir desangrado, insistiendo en que tal pretensión no figura en el pacto: "No lo puedo encontrar: no está en el compromiso" (Escena I, Acto Cuarto). La obsesión de Shylock por la venganza (dimensión vindicativa) le impide ver que una "estricta reciprocidad" no puede ser el horizonte último de la justicia, ya que ésta sólo puede llamarse así cuando garantiza la salvaguarda de los valores humanos fundamentales. Y ese es el horizonte que señala Portia: si bien la 
reciprocidad (el “talión”) es una componente de la justicia; ésta deja de ser tal justicia cuando dicha reciprocidad se invoca para dañar el más importante de los bienes humanos: la vida y la integridad física del individuo. Con ello se pone de relieve la íntima e inescindible relación que debe existir entre justicia y defensa de los valores humanos. No podemos concebir una justicia inhumana. He ahí el mensaje que poco a poco irá calando en el Derecho de la Modernidad. En la justicia debe resplandecer el valor de la condición humana y eso supone garantizar los bienes básicos inherentes a esta condición.

Shylock, arrastrado por su obcecación vindicativa, exige la estricta ejecución de la cláusula penal (cortar una libra de carne) pero Portia lo aprovecha para poner al descubierto los límites de una concepción de la justicia basada en la "estricta" reciprocidad. Obviamente, si la reciprocidad no es "estricta", no procedería calificarla de justicia, puesto que entonces habría espacio para los valores (generosidad, clemencia, etc.). En consecuencia, lo que procede es atenerse a la estricta letra del contrato, excluyendo todo lo no mencionado expresamente en el pacto. Y así lo señala Portia:

(Portia): "Este documento no os concede nada de sangre. Las palabras exactas son 'una libra de carne'. Toma entonces lo debido, toma tu libra de carne, pero al cortarla, si viertes una sola gota de sangre cristiana, tus tierras y bienes, por las leyes de Venecia, quedarán confiscadas para el Estado de Venecia” (Escena I, Acto Cuarto).

Es en ese momento cuando Shylock se da cuenta de que ha perdido la razón en el ámbito público obcecado por su pretensión vindicativa (resentimiento privado) y, entonces, pretende acogerse a la dimensión retributiva, aceptando la indemnización ofrecida por Antonio y Bassanio (el triple de lo prestado). Pero Portia se niega y le obliga a situarse ante las consecuencias de privilegiar en la justicia la dimensión vindicativa (venganza) exigiéndole que ejecute la cláusula penal, tal y como él había pedido:

(Portia): "Así que prepárate a cortar una libra de carne. No viertas sangre, ni cortes más o menos de una libra justa de carne: si tomas más o menos de una libra justa, aunque sea lo que haga más ligera o más pesada en la balanza la vigésima parte de un pobre grano; más aún, si la balanza se 
inclina en la diferencia de un pelo, mueres y todos tus bienes quedan confiscados" (Escena I, Acto Cuarto).

La imposibilidad de ejecutar la cláusula penal ("estricta" reciprocidad) no deja a Shylock otra salida que invocar aquellos valores que había denostado como radicalmente ajenos a la idea de justicia (generosidad, clemencia, perdón). Así pues, declara ante el tribunal que perdona la deuda y renuncia a hacer efectiva la cláusula penal. Pero Portia tampoco le franquea esa salida y, recordando su exigencia de reclamar una "estricta" justicia, asesta el golpe final a su concepción vindicativa, demostrándole que sólo hay justicia donde prevalecen los valores humanos:

(Portia): "La ley tiene todavía algo más que te afecta. Según las leyes de Venecia, si se demuestra que alguno atenta contra la vida de cualquier ciudadano por medos directos o indirectos, la persona contra la que conspire se incautará de la mitad de sus bienes, y la otra mitad irá a las arcas propias del Estado; y la vida del culpable queda a merced del Dux. En esa situación estás, pues resulta que, por acción manifiesta, has conspirado contra la vida del demandado. Arrodíllate, pues, y pide clemencia al Dux" (Escena I, Acto Cuarto).

El Dux se apresura a conceder clemencia antes de que le sea suplicada, pero Shylock, consciente de la trampa a la que se ve arrastrado, se resiste a renunciar a la dimensión vindicativa del talión y rehúsa la clemencia como algo ajeno a la estricta justicia: "No. Tomad también mi vida y todo: no lo perdonéis...”. Y es, entonces, Antonio quien intercede en su favor, utilizando el artificio de su conversión al cristianismo como el instrumento a través del cual conseguirá superar su concepción vindicativa integrando los valores humanos.

En definitiva, el artificio interpretativo de Portia acaba mostrando que la idea moderna de justicia pasa por la integración de dos elementos fundamentales: la legalidad, que garantiza el ejercicio de la razón pública y el ineludible fundamento moral de la legalidad, encarnada en la defensa de los valores humanos fundamentales (entre ellos, los primordiales de la vida y la integridad física), superando la tradicional dimensión vindicativa. 


\section{CRIMEN Y CASTIGO: DERECHO Y JUSTICIA ANTE}

\section{LA DERIVA NIHILISTA DE LA POSTMODERNIDAD}

El pensamiento nihilista de la postmodernidad decadente, que comienza con el post-estructuralismo francés (surgido de la revolución del sesenta y ocho y que hoy resulta hegemónico en occidente), tiene su evidente anticipación literaria en algunas obras inmortales de Fiódor Dostoievski (1821-1881) como Crimen y castigo, Los hermanos Karamazov o Los demonios (Ballesteros, 1998, p. 85-98). En efecto, Dostoievski, "el mejor conocedor del alma humana de todos los tiempos", en palabras de Stefan Zweig (2004, p. 97), describió proféticamente el pensamiento postmoderno en la vida de algunos de sus personajes más célebres, pero también describió con clarividencia la destrucción interior y exterior que sufren estos al eliminar de su vida el sentido y el fundamento moral de la acción humana. Iván Karamazov, Raskólnikov o Stavroguin encarnan la esencia del nihilismo, negando la existencia de la verdad y legitimando incluso el recurso a la violencia, entendida ésta como expresión de la voluntad de poder del "hombre superior", que más adelante perfilaría Nietzsche, el gran profeta y profeso del nihilismo, en su emblemático proyecto del "superhombre"16.

El nihilismo presupone la negación de toda creencia, de todo principio religioso, político y social, extirpando del ser humano cualquier vestigio de conciencia, descartando toda referencia moral, universal y objetiva, que permita distinguir entre el bien y el mal (Talavera, 2014, p. 340-378):

"si Dios no existe, todo está permitido", afirma solemnemente Iván Karamazov (Dostoievski, 2007, p. 941).

Pero en estas obras Dostoievski lucha contra ese futuro fatalista que vislumbra oponiendo al nihilismo el planteamiento ético de otros personajes como Sonia, Aliocha Karamazov o el staret Zósima, que reivindican la condición moral del ser humano, sosteniendo la realidad de

\footnotetext{
${ }^{16}$ Friedrich Nietzsche, devoto lector de Dostoievski, alaba sus escritos y, a pesar del teísmo presente en ellos y de considerarle su perfecto antagonista, afirma sin ambages en $\mathrm{El}$ crepúsculo de los ídolos: "Dostoievski, el único psicólogo, por cierto, del cual se podía aprender algo, es uno de los accidentes más felices de mi vida, más incluso que el descubrimiento de Stendhal" (Nietzsche, 2002, n. 45). Para ahondar en la influencia de Dostoievski en el pensamiento de Nietzsche puede verse: Stellino, 2008, p. 80-99.
} 
la culpa, la necesidad del arrepentimiento o el valor de la expiación, y que apuntan al cristianismo y a los valores trascendentes como la única verdad capaz de superar el nihilismo. Quizá sea en Crimen y Castigo donde esta dialéctica entre el fatalismo nihilista y la visión trascendente se plasme de manera más profunda. Al margen de que Dostoievski tenga personajes más perfectos, la historia de Raskólnikov constituya una de las cimas de la literatura universal, si es que ésta puede definirse no sólo por la excelencia narrativa, sino también - y sobre todo - por la profundidad que encierra su reflexión sobre el espíritu humano.

La figura de Raskólnikov responde a la de una especie de anti-héroe trágico, cuya tragedia interior consiste, precisamente, en darse cuenta de que no es un héroe (un ser superior) sino un simple ser humano, cuya conciencia le ata inevitablemente a unas categorías del bien y del mal, de lo justo y de lo injusto, que él considera propias de seres inferiores, de quienes se someten al orden establecido, porque no son sino sumisas ovejas de un rebaño, incapaces de concebir una idea más alta de humanidad. Raskólnikov representa y encarna el reverso de la figura de Shylock. El judío veneciano concibe la ley como un instrumento valioso, porque permite al débil vengarse del fuerte, amparado y legitimado por la propia estructura del Estado, cuyo fundamento último radica precisamente en el respeto a la ley. Por el contrario, el estudiante ruso desprecia la ley precisamente porque los fuertes, los seres superiores, jamás se someten a ella y acaban imponiendo a los débiles su ideal superior de justicia, un ideal que los legitima para ejecutar cualquier acto que consideren beneficioso para humanidad (incluido el homicidio).

Raskólnikov jamás acepta que fueran el odio y el resentimiento hacia la vieja usurera los que le impulsaran a ejecutar el crimen. En su concepción del "hombre superior" no cabe el sentimiento de venganza, sus actos responden siempre a la realización de su ideal de justicia y se legitiman por su orientación hacia el futuro beneficio de la humanidad. La venganza es, en realidad, un sentimiento propio de los seres inferiores. La experiencia trágica del remordimiento (del sentimiento de culpa) que, a su pesar, experimenta Raskólnikov, sólo manifiesta su debilidad y cobardía; la profunda decepción que le produce constatar el abismo existente entre lo que es y lo que querría ser, pero que no le hace recapacitar y aceptar la 
dimensión moral del ser humano, la existencia de unos principios naturales y objetivos que fundamentan los conceptos de bien y de mal, de lo justo y de lo injusto. El castigo, su confinamiento en una cárcel de Siberia, no ejerce sobre él un efecto expiatorio y reparador; no sana su conciencia devolviéndole a una concepción racional y universal de la justicia (sigue convencido de que su crimen fue justo); solamente le impulsa a resignarse a su condición de "ser inferior" y a sobrellevarla anestesiado por el amor de Sonia.

La novela nos presenta a Rodion Romanóvich Raskólnikov, un joven estudiante de derecho en la Rusia zarista, que ve trabados sus sueños por la miseria en la cual malviven él y su familia. Indignado porque su hermana Dunia va a casarse por dinero con un hombre al que no ama y asqueado por su situación miserable, decide matar a Alina Ivanovna, una anciana vil y egoísta, que ejerce de prestamista y a la que ha acudido en varias ocasiones. Sin embargo, Raskolnikov, a pesar de su pobreza, no resuelve asesinar a la anciana motivado por la codicia, sólo para robarle (de hecho regala a una familia desconocida todo ese dinero para que entierren al padre). La justificación de ese crimen responde, según él, a una exigencia moral, a un deber de justicia: considera a la usurera un ser humano inútil y pernicioso para la sociedad y su muerte un enorme beneficio para todos:

Cien, mil obras útiles se podrían mantener y mejorar con el dinero que esa vieja legará a un monasterio. Miles de vidas, se podrían encauzar por el buen camino; muchas familias se podrían salvar de la miseria, del vicio, de la degradación, de la muerte, de los hospitales para enfermedades venéreas, todo gracias al dinero de esa mujer. Si uno la matara y se apoderase de su dinero para destinarlo al bien de la humanidad, ¿crees que el crimen, el pequeño crimen, quedaría ampliamente justificado por el número de buenas acciones del criminal? Por una sola vida, miles salvados de la corrupción. Por una sola muerte, cien vidas. Es una cuestión matemática. Además, ¿qué puede pesar en la balanza social la vida de una anciana avara, estúpida y cruel? Lo mismo que la vida de un piojo o de una cucaracha. Y yo diría que menos, pues la vieja es un ser nocivo, lleno de maldad, que dificulta la vida de otros seres (Dostoievski, 1985, p. 89).

Pero Raskolnikov no pretende justificar su acción por un mero cálculo de utilidad, va mucho más allá: sostiene una posición intelectual y moral muy cercana a la figura del "superhombre" (übermensch) que Nietzsche desarrolló posteriormente en Así habló Zaratustra (Nietzsche, 2011, 
Prólogo, n. 3 y 4) y otras obras ${ }^{17}$. Se trata de una posición que asume plenamente el nihilismo; es decir, el ocaso de todos los valores que sustentan la civilización occidental (el concepto nietzscheano de "muerte de Dios”) y la necesidad de crear un mundo nuevo basado en la acción de los "hombres superiores", espíritus libres de la sumisión del rebaño (el orden establecido), capaces de instaurar los nuevos valores de una nueva civilización, desafiando las reglas, aun a costa de su propio sacrificio (Nietzsche, 2011, Prólogo, n. 2, y parte IV, “Jubilado”). Así lo expresa Raskólnikov en su extraordinaria conversación con Porfiri Petrovitch:

Mi opinión es que los hombres pueden dividirse, en general y de acuerdo con el orden de la misma naturaleza, en dos categorías: una inferior, la de los individuos ordinarios, es decir, el rebaño cuya única misión es producir seres semejantes a ellos, y otra superior, la de los verdaderos hombres, que se complacen en dejar oír en su medio 'palabras nuevas'. [...]. La primera categoría se compone de hombres conservadores, prudentes, que viven en la obediencia porque esta obediencia les encanta. Y están obligados a obedecer porque ese es su papel en la vida y ellos no ven nada humillante en desempeñarlo. En la segunda categoría, todos faltan a las leyes, o por lo menos, todos tienden a violarlas por todos sus medios. En la mayoría de los casos, estos hombres reclaman, con distintas fórmulas, la destrucción del orden establecido en provecho de un mundo mejor. [...]. La masa no les reconoce nunca ese derecho y los decapita o los ahorca... hasta el día en que generaciones futuras de esa misma masa erigen estatuas en honor de esos ajusticiados y crean culto en torno a ellos. Los hombres de la primera clase son dueños del presente, los de la segunda del provenir [...]. Los dos tienen su razón de existir (Dostoievski, 1985, p. 286).

Raskólnikov asume aquí el ocaso de una sociedad cuyas reglas (presuntamente morales) protegen a personajes miserables como Alina (la usurera); permiten la miseria y la vejación de personas buenas como su hermana Dunia; o mantienen en el poder a corruptos y explotadores como los zares. Esas realidades son el signo de la inevitable decadencia y muerte de los principios morales tradicionales y del nacimiento de una nueva idea

\footnotetext{
${ }_{17}$ Aunque es un tema controvertido, parece claro el parentesco entre la posición de Raskólnikov respecto a los 'hombres superiores' que pueden prescindir de la moral en aras de un futuro mejor para la humanidad (que justifica sus acciones) y la teoría del 'Superhombre', desarrollada por el filósofo alemán. Resultaría superficial identificar ambas propuestas desde el punto de vista filosófico, pero resulta innegable apreciar una estrecha relación entre ambas (Megía, 2000, p. 172-179).
} 
de justicia, que ya no brota de su adecuación a una realidad superior, trascendente, sino del propio espíritu del "hombre superior", que impone su "genio" (la idea nietzscheana de "voluntad de poder") cambiando la realidad social, aun a precio de sangre, liberándola de la esclavitud y elevándola siempre a un estadio de mayor perfección. Para Raskólnikov, sólo quien goza de la excepcionalidad de espíritu de los "seres superiores" es capaz de concebir una idea más perfecta del mundo y es capaz de instaurarla. Y está convencido de que esos avances y conquistas sólo pueden realizarse contraviniendo las reglas del Derecho vigente $\mathrm{y}$, en no pocas ocasiones, incluso con el derramamiento de sangre:

En mi opinión, si los descubrimientos de Képler o Newton, por una circunstancia o por otra, no hubieran podido llegar a la humanidad, sino por el sacrificio de una, cien o más vidas humanas que hubieran sido un obstáculo para ello, Newton hubiera tenido el derecho, e incluso el deber, de sacrificar esas vidas a fin de facilitar la difusión de sus descubrimientos por todo el mundo. Eso no quiere decir, ni mucho menos, que Newton tuviera derecho a asesinar a quien se le antojara, o a cometer toda clase de robos. [...]. Licurgo, Solón, Mahoma, Napoleón, etc., todos, hasta los más próximos a nosotros, han sido criminales, ya que al promulgar nuevas leyes violaban las antiguas, que habían sido respetadas por la sociedad y transmitidas por generaciones, y también porque esos hombres no retrocedieron ante los derramamientos de sangre, y muchas veces de sangre inocente $\mathrm{y}$ a veces heroicamente derramada para defender las antiguas leyes, por poca que fuese la utilidad que obtuvieran de ello. Incluso puede afirmarse que la mayoría de esos bienhechores y guías de la humanidad han hecho correr ríos de sangre. Mi conclusión es que no solo los grandes hombres, sino todos aquellos que se elevan, por poco que sea, por encima del nivel medio, y que son capaces de decir algo nuevo, son por naturaleza, inevitablemente criminales, en un grado variable, como es lógico. Si no fueran criminales les sería difícil salir de la rutina. No quieren permanecer en ella, y yo creo que es provechoso que no lo hagan (Dostoievski, 1985, p. 285).

He aquí una evidente prefiguración de lo que posteriormente Nietzsche describiría como la esencia del "superhombre": el tránsito desde la aceptación de unos principios morales universales y objetivos, hacia la identificación de la moral con la "voluntad de poder", con el espíritu del "hombre superior" (Nietzsche, 2011, "De la superación de sí mismo"). A partir de estos presupuestos, Raskolnikov pretende hacer una especie de experimento moral para determinar si pertenece a esa clase de "seres 
superiores”. En efecto, con el asesinato de la usurera pretende asumir - en clave nietzscheana - el espíritu de los "hombres excepcionales"; imponer su instinto, el poder de su voluntad (libre del prejuicio moral) y liberar a la humanidad de un ser maligno y dañino, aun a costa de vulnerar la legalidad (Nietzsche, 2006, II, n. 24). Siendo así, no debería sentir ningún "remordimiento" por el crimen, sino al contrario considerarse un auténtico benefactor de la humanidad. Sólo quien es un "simple mortal" - una oveja del rebaño - puede sentirse culpable de perpetrar un delito y transgredir la ley.

Pero su planteamiento zozobra cuando se ve obligado a asesinar también a Lisbeth, la hermana inocente de la usurera, que lo sorprende en el lugar del crimen. Esa acción abre una importante brecha en su convicción, por donde comienza a abrirse su tormento interior: ¿puede justificarse cualquier acto (incluido el asesinato de un ser inocente) a cambio de un bien superior de la humanidad? En efecto, la idea que sostiene Raskólnikov sobre el "hombre superior" incluye una evidente dimensión ética. No pretende justificar al psicópata o al criminal sanguinario (también Nietzsche precisará en Zaratustra que la figura del "superhombre" no es la del salvaje). El "ser superior" es alguien cuyo espíritu creativo es capaz de ver más allá; es capaz de atisbar un bien superior para el género humano y asume el derramamiento de sangre como medio indispensable para alcanzarlo. Ese "ser superior" pretende realizar un ideal de justicia, pero se trata de un ideal que jamás puede conseguirse con el sometimiento a las reglas del Derecho, impuestas por el Estado, que siempre son esclavizadoras, conservadoras, enemigas de todo progreso y, en consecuencia, amparadoras de injusticia y corrupción.

El planteamiento del "hombre excepcional" que invoca Raskólnikov recuerda una vez más la tensión existente entre nomos (ley) y diké (justicia), ya suscitada por Antígona, pero desde una perspectiva inversa. En efecto, la tensión entre el edicto de Creonte (nomos), que prohíbe bajo pena de muerte dar sepultura a un traidor a la polis, y las exigencias superiores de la justicia divina (diké), a la que se remite Antígona para sepultar a su hermano, constituyen el presupuesto del Estado de Derecho: la ley (nomos) debe fundamentarse sobre unos principios universales de justicia (diké) que legitiman su obediencia. Sin ese fundamento, la ley no es 
más que una mera expresión coactiva del poder que, si bien puede imponerse por la fuerza, no podrá calificarse como justa ni exigir su acatamiento desde una perspectiva moral (podrá ser una obligación legal pero no un deber moral). En el planteamiento de Raskólnikov, el "hombre excepcional" que se siente legitimado para actuar al margen de la legalidad, no lo hace porque aprecie en la ley un déficit de legitimidad (porque no la considere expresión de unos principios universales de justicia), sino porque ninguna ley puede abarcar el ideal de justicia que concibe la grandeza de su espíritu. Hasta el punto de que sus acciones podrán ser calificadas de ilegales (desde el sistema de reglas de los seres inferiores) e incluso castigadas, pero nunca podrán ser calificadas como injustas, puesto que la idea de justicia del ser superior mira al bien de la humanidad y acabará triunfando en las generaciones posteriores, y convirtiéndose en ley:

¿Por qué es un crimen? ¿Qué quiere decir la palabra 'crimen'? Tengo la conciencia tranquila. Sin duda, he cometido un acto ilícito; he violado las leyes $\mathrm{y}$ he derramado sangre. iPues cortadme la cabeza, y asunto concluido! Pero en este caso, no pocos bienhechores de la humanidad, que se adueñaron del poder en vez de heredarlo desde el principio de su carrera, debieron ser entregados al suplicio. Lo que ocurre es que estos hombres consiguieron llevar a cabo sus proyectos; llegaron hasta el fin de su camino y su éxito justificó sus actos. En cambio, yo no supe llevar a buen término mi plan... y, en verdad, esto demuestra que no tenía derecho a intentar ponerlo en práctica (Dostoievski, 1985, p. 537).

Raskolnikov (al igual que el "superhombre" de Nietzsche) no concibe la existencia de unos principios universales de justicia, inherentes a la naturaleza humana, que hay que descubrir y respetar, y que deben fundamentar la legalidad. Para él la justica es algo que está más allá de las normas, es algo que se genera en la mente de los hombres excepcionales y que acaba imponiéndose en la realidad y generando un beneficio para la humanidad. Raskólnikov preanuncia con esto la esencia nihilista del hombre postmoderno: la subjetivización de la realidad (consecuencia del ocaso de toda instancia superior a la propia "voluntad de poder") que conduce a considerarla como un simple relato - una "fábula", en palabras de Vattimo que puede recrearse y contarse de cualquier otra manera y sustentarse sobre cualquier otro valor y fundamento (Vattimo, 1994, p. 26-38). 
Raskólnikov pretende ser, en efecto, ese superhombre creador de valores nuevos y autor de un relato alternativo de la realidad, pero su posición nihilista choca frontalmente con unos principios morales, que no consigue ignorar ni extirpar de su espíritu, y que le obligan a aceptar que tiene "conciencia", algo propio de los seres inferiores. En consecuencia, a pesar de sus piruetas intelectuales, no acaba de saber a ciencia cierta si su crimen responde al espíritu creador del hombre nuevo, o si en realidad no es más que la satisfacción miserable de un deseo venganza, motivado por el odio y el rencor hacia la usurera y lo que ella representa. Cuando confiesa a Sonia su crimen lo manifiesta expresamente:

¿Qué habría ocurrido si Napoleón se hubiese encontrado en mi lugar y no hubiera tenido, para tomar impulso en el principio de su carrera, ni Tolón, ni Egipto, ni el paso de los Alpes por el Mont Blanc, sino que, en vez de todas estas brillantes hazañas, sólo hubiera dispuesto de una detestable y vieja usurera, a la que tendría que matar para robarle el dinero..., en provecho de su carrera, entiéndase? ¿Se habría decidido a matarla no teniendo otra alternativa? ¿No se habría detenido al considerar lo poco que este acto tenía de heroico y lo mucho que ofrecía de criminal...? Te confieso que estuve mucho tiempo torturándome el cerebro con estas preguntas (Dostoievski, 1985, p. 437).

Raskólnikov comienza a ser devorado por esa batalla interior y a sufrir un proceso de deterioro psicológico que lo mantendrá en un estado de angustia, delirio e inconsciencia, bordeando la locura. Se repite, una y otra vez, que tiene la conciencia tranquila y que ha actuado movido por un deber moral, pero lo cierto es que su vida se va tornando más y más desequilibrada. El castigo de su crimen, en realidad, es un castigo psicológico, interno y espiritual, que nace de su profunda incapacidad para no sentir remordimientos frente a la atrocidad del doble homicidio. $\mathrm{Su}$ sentimiento de culpa le demuestra que no pertenece a esa supuesta clase de "seres superiores" sino al tipo de "hombre inferior" que tanto desprecia, pero que es en realidad el verdadero hombre, el ser humano que se rige por criterios morales, que entiende el sentido del Derecho en la sociedad:

¿Qué importa la vieja! [...] Admitamos que la vieja fue un error, no se trata de ella. La vieja no fue más que un obstáculo... Yo quería saltarlo lo antes posible... iNo maté una criatura humana, sino un principio! iMaté el principio, pero no supe pasar por encima de él, quedé del otro lado...! iNo he sabido más que matar! (Dostoievski, 1985, p. 287). 
La expresión "no he sabido más que matar" delata su fracaso. Raskólnikov no ha logrado su propósito (realizar el acto de un ser superior), simplemente ha transgredido un principio moral (no matar), pero no ha sido capaz de suprimirlo y sustituirlo por el supremo valor de su "voluntad de poder". El asesinato de Lisbeth - la hermana inocente de Alina, amada por sus buenas obras entre los que la conocían - que se ve "obligado" a cometer para no ser descubierto, será quien le impida "pasar por encima del principio" (la dimensión moral del hombre inferior) y le arrastre a la enajenación hasta el momento de entregarse.

Finalmente, incapaz de sobreponerse a su tortura interior, Raskolnikov se decide confesar el crimen, aun cuando no existe ninguna prueba contra él. Pero lo hace sólo para acabar con la tortura interior que le enajena y le desequilibra, sin modificar aparentemente su posición intelectual. Se niega a reconocer la inmoralidad de su doble asesinato; al contrario, se manifiesta convencido de la justicia de ese acto y lo único que lamenta es su propia debilidad y cobardía, que le han hecho sucumbir al sentimiento de culpa y le han impedido mostrarse como el "superhombre" que habría querido ser:

- ¿Mi crimen? ¿Qué crimen? - exclamó el joven en un repentino acceso de furor -. ¿El de haber matado a un gusano venenoso, a una vieja usurera que hacía daño a todo el mundo, a un vampiro que chupaba la sangre a los necesitados? Un crimen así basta para borrar cuarenta pecados. No creo haber cometido ningún crimen y no trato de expiarlo. ¿Por qué me han de gritar por todas partes: iHas cometido un crimen!? Ahora que me he decidido a afrontar este vano deshonor me doy cuenta de lo absurdo de mi proceder. Sólo por cobardía y por debilidad voy a dar este paso..., o tal vez por el interés de que me habló Porfirio.

- Pero ¿qué dices, Rodia? - exclamó Dunia, consternada -. Has derramado sangre.

- Sangre..., sangre... - exclamó el joven con creciente vehemencia -. Todo el mundo la ha derramado. La sangre ha corrido siempre en oleadas sobre la tierra. Los hombres que la vierten como el agua obtienen un puesto en el Capitolio y el título de bienhechores de la humanidad. [...]. Cuando fracasan, incluso los mejores proyectos parecen estúpidos. [...]. Si hubiese triunfado, me habrían tejido coronas; en cambio, ahora creen que sólo sirvo para que me echen a los perros.

- Pero ¿qqué dices, Rodia?

- Me someto a la ética, pero no comprendo en modo alguno por qué es más glorioso bombardear una ciudad sitiada que asesinar a alguien a hachazos. El respeto a la ética es el primer signo de impotencia. Jamás he estado 
tan convencido de ello como ahora. No puedo comprender, y cada vez lo comprendo menos, cuál es mi crimen (Dostoievski, 1985, p. 532).

Dostoievski deja entrever que Raskolnikov tiene su conciencia aparentemente tranquila porque está profundamente estropeada, ha perdido toda capacidad de sopesar la magnitud moral de sus actos. $Y$ esa es su tragedia más profunda; la tragedia más profunda del nihilista postmoderno: la inconsistencia de su propia realidad, la percepción del sinsentido que supone la ausencia de todo valor moral. En el epílogo de la obra, mientras cumple condena en las cárceles en Siberia, Raskólnikov sufre por el orgullo herido, por la humillación de comprobar que no es un "ser superior"; pero lo que en realidad desearía es tener un auténtico remordimiento, poder experimentar un verdadero sufrimiento moral (culpa) y no una mera frustración; reconocerse culpable y querer expiar su crimen es lo le haría sentirse verdaderamente humano:

Pero su vergüenza no la provocaban los grilletes ni la cabeza rapada. Le habían herido cruelmente en su orgullo, y era el dolor de esta herida lo que le atormentaba. iQué feliz habría sido si hubiese podido hacerse a sí mismo alguna acusación! iQué fácil le habría sido entonces soportar incluso el deshonor y la vergüenza! Pero, por más que quería mostrarse severo consigo mismo, su endurecida conciencia no hallaba ninguna falta grave en su pasado. Lo único que se reprochaba era haber fracasado, cosa que podía ocurrir a todo el mundo. Se sentía humillado (Dostoievski, 1985, p. $556)$.

Con la desesperación de Raskólnikov (se resiste a entregarse pero también a suicidarse), Dostoievski pone de manifiesto la resistencia innata de todo ser humano frente al nihilismo; la imperiosa necesidad de encontrar un sentido a la realidad, un sentido que remite a la moralidad y que exige, en última instancia, recuperar la ontología, aceptar el valor trascendente de la naturaleza humana y el carácter ético de la acción humana:

Acababa de acordarse de estas palabras de Sonia: 'Ve a la primera esquina, saluda a la gente, besa la tierra que has mancillado con tu crimen y di en voz alta, para que todo el mundo te oiga: iSoy un asesino!'. Ante este recuerdo empezó a temblar de pies a cabeza. [...]. La sensación se apoderó de él con tal fuerza, que sacudió su cuerpo, iluminó su corazón como una centella y al punto se convirtió en fuego devorador. Una inmensa ternura se adueñó de él; las lágrimas brotaron de sus ojos. Sin vacilar, se dejó caer de rodillas en el suelo, se inclinó y 
besó la tierra, el barro, con verdadero placer. Después se levantó y en seguida volvió a arrodillarse (Dostoievski, 1985, p. 542).

He ahí la intuición más poderosa que Dostoievski transmite en estas páginas: la necesidad de rescatar al hombre de las sombras nihilistas y devolverlo a la trascendencia, donde se encuentra el núcleo de lo genuinamente humano que encarna paradigmáticamente el personaje de Sonia: víctima de todas las injusticias posibles y, sin embargo, exponente sublime de los valores humanos más profundos. En efecto, también Sonia ha transgredido las normas morales (es una prostituta) pero no siente rencor ni odio, sino amor por su familia y por los demás; no pretende justificar sus actos negando la moralidad sino que la asume en toda su profundidad y acepta el sufrimiento y la injusticia como expiación. En Sonia la realidad del sufrimiento y de la injusticia adquieren sentido; un sentido que no es ni la pura subjetividad (a la que pretende reducirlo Raskólnikov) ni la pura facticidad (a la que pretende resignarse su padre Marmeládov); un sentido que consiste en descubrir los valores éticos universales que nos constituyen como humanos. Es precisamente eso lo que desconcierta a Raskólnikov, que alguien pueda encontrar sentido al sufrimiento y a la injusticia:

¿Cómo es posible que tanta ignominia, tanta bajeza, se compaginen en ti con otros sentimientos tan opuestos, tan sagrados? Sería preferible arrojarse al agua de cabeza y terminar de una vez (Dostoievski, 1985, p. 347).

Dostoievski invita, pues, a redescubrir el sentido de la realidad, aquello que sólo el hombre posee y que está inserto en la propia naturaleza humana (Husserl, 2008, p. 108-135), y deja entrever implícitamente el verdadero sentido del Derecho. Para el nihilista Raskólnikov, las normas no son más que ataduras que esclavizan y sobre las que hay que pasar para imponer la propia concepción subjetiva de la realidad (voluntad de poder); pero dicha actitud no consigue erradicar algo tan profundamente arraigado en la naturaleza humana como apreciar la inocencia de otro ser (Lisbeth) y la atrocidad de asesinarlo. Para el jurista Porfiri Petrovitch, el sentido del Derecho se encuentra en su capacidad de rescatar al hombre del subjetivismo de su voluntad y situarle en la objetividad de la justicia, en las coordenadas esenciales de su dimensión relacional; esto es, en recordarle la existencia del "otro" como un igual y como un sujeto de reconocimiento y de 
respeto absoluto, que excluye toda instrumentalización (Ballesteros, 2007, p. 90-135). Sonia complementa la visión del juez puesto que, para ella, las reglas tienen sentido por su intrínseca moralidad. Son la imprescindible referencia objetiva que vincula al hombre con la expresión más profunda de su humanidad: la dimensión moral de sus actos. Cuando Raskólnikov pretende explicarle la teoría que justifica su crimen, ella se remite siempre a la dimensión moral del acto:

- Al fin y al cabo, Sonia, yo no he dado muerte más que a un vil y malvado gusano.

- Ese gusano era una criatura humana.

[...].

- Has de saber que cuando fui a casa de la vieja, yo solamente deseaba hacer un experimento.

- Usted mató.

[...].

- ¿Qué debes hacer? - exclamó la muchacha. Ve inmediatamente a la próxima esquina, arrodíllate y besa la tierra que has mancillado. Después inclínate a derecha e izquierda, ante cada persona que pase, y di en voz alta: iHe matado! Entonces Dios te devolverá la vida.

[...].

- ¿Quieres que vaya a presidio, Sonia? -preguntó con acento sombrío-. ¿Pretendes que vaya a presentarme a la justicia?

- Debes aceptar el sufrimiento, la expiación, que es el único medio de borrar tu crimen" (Dostoievski, 1985, p. 442).

En definitiva, el genio de Dostoievski prefigura el actual planteamiento del hombre postmoderno (anclado en el superhombre nietzscheano), con su tendencia a la subjetivización de la realidad y la consiguiente disolución del Derecho, que cada vez funciona más como mero instrumento para la satisfacción de deseos (convertidos en derechos) que como vínculo ineludible del sujeto con las exigencias morales objetivas de la naturaleza humana en su dimensión social (la justicia). Y es también el propio Dostoievski quien nos apunta la vía de salida: recuperación del sentido trascendente de la realidad y redescubrimiento de la dimensión ontológica y antropológica del Derecho.

\section{REFERENCIAS}

BALLESTEROS, Jesús. Postmodernidad: decadencia o resistencia. Madrid: Civitas, 1998.

BALLESTEROS, Jesús. Sobre el sentido del ferecho. Madrid: Tecnos, 2007. 
BOTERO, Adolfo. Derecho y Literatura: un nuevo modelo para armar. Instrucciones de uso. In: CALVO, José (Dir.). Implicación Derecho Literatura. Granada: Comares, 2008. p. 33-38.

CALVO, José. Derecho y Literatura. Intersecciones instrumental, estructural e institucional. In: CALVO, José (Dir.) Implicación Derecho Literatura. Granada: Comares, 2008. p. 3-28.

DOSTOIEVSKI, Fiodor. Los hermanos Karamazov. Barcelona: Cátedra, 2000.

DOSTOIEVSKI, Fiodor. Crimen y castigo. Madrid: EDAF, 1985.

FERNÁNDEZ-GALIANO, Manuel. Tragedias de Esquilo. Madrid: Gredos, 2002.

FOUCAULT, Michel. Vigilar y castigar. Madrid: Biblioteca Nueva, 2012.

HERRERAS, Enrique. La idea de la justicia en la obra de Esquilo. Daimon, n. 45, p. 55-70, 2008.

HESÍODO. Los trabajos y los días. In: HESÍODO. Obras y fragmentos. Trad. De A. Pérez y A. Martínez. Madrid: Gredos, 1990. p. 55-107.

HUSSERL, Edmund. La crisis de las ciencias europeas y la fenomenología trascendental. Buenos Aires: Prometeo, 2008.

KARAM, André; MAGALHÃES, Roberta. Derecho y Literatura. Acercamientos y perspectivas para repensar el Derecho. Revista electrónica del Instituto de Investigaciones 'Ambrosio L. Gioja', n. 4, p. 164-213, 2009. Disponible en: <www.derecho.uba.ar/revistagioja>. Acceso en: 20 mayo 2015.

MEGÍA, Jorge Mario, Nietzsche y Dostoievski: filosofía y novela. Medellín: Ed. Universidad de Antioquia, 2000.

NIETZSCHE, Friedrich. El crepúsculo de los ídolos o cómo se filosofa con el martillo. Madrid: EDAF, 2002.

NIETZSCHE, Friedrich. La genealogía de la moral. Madrid: Alianza, 2006.

NIETZSCHE, Friedrich. Así habló Zarathustra: un libro para todos y para nadie. Madrid: Alianza, 2011.

NUSSBAUM, Martha. La fragilidad del bien. Madrid: Visor, 1995.

NUSSBAUM, Martha. Justicia poética: La imaginación literaria y la vida pública. Santiago de Chile: Andrés Bello, 1997.

OST, François. Raconter la loi: Aux sources de l’imaginaire juridique. Paris: Odile Jacob, 2004.

OST, François. Sade et la loi. Paris: Odile Jacob, 2005.

RODRÍGUEZ ADRADOS Francisco. La democracia ateniense. Alianza: Madrid, 1998.

RORTY, Richard. Contingencia, ironía y solidaridad. Paidós: Barcelona, 1991.

RORTY, Richard. Objetividad, relativismo y verdad. Paidós: Barcelona, 1996. 
RORTY, Richard. Filosofía y futuro. Gedisa: Barcelona, 2002.

STELLINO, Paolo. Límites y confines de la venganza en Nietzsche y Esquilo. In: ARENAS, Francisco; GIANCRISTOFARO, Luca; STELLINO, Paolo (Ed.). Nietzsche y la hermenéutica. Valencia: Nau Llibres, 2007. p. 621-630.

STELLINO, Paolo. El descubrimiento de Dostoievski por parte de Nietzsche. Contrastes, XIII, p. 80-99, 2008.

TALAVERA, Pedro. Derecho y literatura. Granada: Comares, 2006.

TALAVERA, Pedro. Economicism and Nihilism in the eclipse of Humanism. Humanities, N. 3, p. 340-378, 2014.

VALVERDE, José María. Introducción, traducción y notas. In: SHAKESPEARE, W. La doma de la furia y El mercader de Venecia. Barcelona: Planeta, 2003.

VÁSQUEZ, Adolfo. Rorty: pragmatismo, ironismo liberal y solidaridad. $A$ Parte Rei, n. 39, p. 1-9, 2005. Disponible en: <http://serbal.pntic.mec.es / cmunoz11/index.html >. Acceso en: 20 mayo 2015.

VÁSQUEZ, Adolfo. Rorty: el giro narrativo de la ética o la filosofía como género literario. Revista Philosophica, n. 29, p. 323-333, 2006.

VATTIMO, Gianni. Más allá del sujeto. Barcelona: Paidós, 1989.

VATTIMO, Gianni. El fin de la modernidad. Barcelona: Planeta, 1994.

ZWEIG, Stefan. Tres maestros: Balzac, Dickens, Dostoievski. Barcelona: Acantilado, 2004. 